\title{
Enzymatic Synthesis of Astaxanthin $n$-Octanoic Acid Esters
}

\author{
Masahiro Nakao ${ }^{1}$, Motoo Sumida ${ }^{2}$, Kenji Katano ${ }^{2}$ and Harukazu Fukami ${ }^{3 *}$ \\ ${ }^{1}$ Institute for Advanced Technology, Technological Development Center, Suntory Ltd. (5-2-5, Yamazaki, Shimamoto-cho, Mishima-gun, \\ Osaka 618-0001, JAPAN) \\ ${ }^{2}$ Institute for Health Care Science, Technological Development Center, Suntory Ltd. (5-2-5, Yamazaki, Shimamoto-cho, Mishima-gun, \\ Osaka 618-0001, JAPAN) \\ ${ }^{3}$ Department of Bioscience and Biotechnology, Faculty of Bioenvironmental Science, Kyotogakuen University (1-1 Nanjyo, Sogabe-cho, \\ Kameoka-city, Kyoto 621-8555, JAPAN)
}

\begin{abstract}
We examined the enzymatic synthesis of astaxanthin $\boldsymbol{n}$-octanoic acid esters. Carriers for the immobilized enzyme and reaction conditions such as water content, reaction temperature, and time were examined using Candida cylindracea lipase (Lipase $\mathrm{OF}^{\circledR}$ ). Lipase $\mathrm{OF}^{\circledR}$ immobilized by a hydrophobic anion exchange resin $(10 \% \mathrm{w} / \mathrm{w}$ content of lipase) gave the best yield in the esterification reaction of astaxanthin. Two milligrams of astaxanthin per $750 \mu \mathrm{L}$ tri-n-octanoin (ca. $0.3 \%$ ) was optimum because of the low solubility of tri-n-octanoin. The esters were obtained in a yield of $36.4 \%$ under the optimal reaction conditions.
\end{abstract}

Key words: astaxanthin, $n$-octanoic acid, Candida cylindracea lipase, esterification.

\section{INTRODUCTION}

Astaxanthin $\left(3,3^{\prime}\right.$-dihydroxy- $\beta, \beta^{\prime}$-carotene-4, $4^{\prime}$-dione, Fig. 1) and related compounds are one class of carotenoids. They are tangerine-colored pigments that are found widely in Crustacea such as shrimps or crabs, in flesh or the eggs of redfish or trout, and on the body surface of sea bream, carp, and goldfish among others ${ }^{1}$. These compounds have remarkable antioxidant activities and are used as health foods ${ }^{2,3)}$.

For their color and physiological function (antioxidant action), astaxanthins are used as natural colorants, cosmetics, and in health foods. For such use, astaxanthins are extracted from Euphausiacea, shrimp, crab, Phaffia yeast or Chlorophyceae, and Haematococcus ${ }^{11}$. Astaxanthin has been synthesized chemically and is used as a feed additive for the purpose of coloring cultured fish ${ }^{4}$. In nature, astaxanthin is present as free astaxanthin or astaxanthin fatty acid esters (monoester or diester) singly or in a mixture ${ }^{5}$. These astaxanthin esters are known to be usually long chain fatty acid esters including saturated fatty acids such as palmitic acid and stearic acid and unsaturated fatty acids such as oleic acid, linoleic acid, and linolenic acid ${ }^{6)}$.

Several methods of obtaining ester derivatives from free astaxanthin have been published, which consist of esterification reactions of astaxanthin and a long chain fatty acid using lipase as a catalyst ${ }^{7)}$ and chemically synthesizing palmitic acid ester ${ }^{8}$. By using lipase, astaxanthin diesters were also converted to the corresponding monoesters ${ }^{9}$. In our previous report ${ }^{10)}$, we chemically synthesized astaxanthin $n$-octanoic acid monoester and diester (Fig. 1), and we found the esters are better oral-absorbability than free astaxanthin or Haematococcus algae derived astaxanthin (an astaxanthin derivative mixture esterified by long-chain fatty acid). So far, it is known that medium-chain fatty acid astaxanthin esters such as $n$-octanoic acid or $n$-dodecanoic

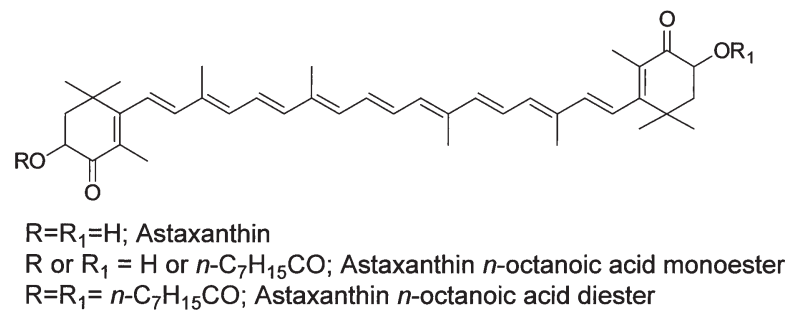

Fig. 1 The Chemical Structure of Astaxanthins.

\footnotetext{
*Correspondence to: Harukazu Fukami, Department of Bioscience and Biotechnology, Faculty of Bioenvironmental Science, Kyotogakuen University, 1-1 Nanjyo, Sogabe-cho, Kameoka-city, Kyoto 621-8555, JAPAN

E-mail: fukami@kyotogakuen.ac.jp
}

Accepted March 21, 2008 (received for review February 19, 2008)

Journal of Oleo Science ISSN 1345-8957 print / ISSN 1347-3352 online

http://www.jstage.jst.go.jp/browse/jos/ 
acid are present in certain kinds of Chlorophyceae and plants although in very small amounts ${ }^{6}$. In particular, the presence of $n$-decanoic acid astaxanthin ester has only been suggested, but it has not been specified as a compound ${ }^{11}$.

In this report, we examined the enzymatic synthesis of $n$-octanoic acid esters of astaxanthin for use as food additives.

\section{EXPERIMENTAL}

\subsection{Chemicals}

Free astaxanthin was purchased from Wako Pure Chemical Industry, Ltd. The carriers for enzyme immobilization were a hydrophobic anion exchange resin (Dowex MARATHON ${ }^{\circledR}$ WBA, Dow Chemical), a hydrophobic adsorptive resin (TOYOPEARL ${ }^{\circledR}$ Phenyl-650S, Tosoh Corporation), an aromatic adsorptive resin $\left(\right.$ DIAION $^{\circledR}$ HP20, $^{-}$ Mitsubishi Chemical Corporation), a methacryl adsorptive resin (DIAION ${ }^{\circledR}$ HP1MG: Mitsubishi Chemical Corporation), a high porous-type aromatic adsorptive ion exchange resin (DIAION ${ }^{\circledR}$ HPA25: Mitsubishi Chemical Corporation), and Celite ${ }^{\circledR}$ (Celite Corporation). A Candida cylindracea lipase (Lipase $\mathrm{OF}^{\circledR}$; powder; Meito Sangyo Co. Ltd.) was used as the lipase.

\subsection{Immobilization of lipase}

In each case the suspension of the resin or gel and Lipase $\mathrm{OF}^{\mathbb{Q}}$ solution was dried under reduced pressure to obtain the indicated amounts of immobilized enzyme product. One hundred grams of anion exchange resin (Dowex MARATHON $^{\circledast}$ WBA) was suspended in $80 \mathrm{~mL}(5,760,000$ units) of Lipase $\mathrm{OF}^{\circledR}$ solution to yield $71.0 \mathrm{~g}$ WBA-OF. One hundred $\mathrm{mL}$ of a hydrophobic adsorptive resin (TOYOPEARL ${ }^{\circledR}$ Phenyl-650S) was suspended in $80 \mathrm{~mL}(5,760,000$ units) of Lipase $\mathrm{OF}^{\circledR}$ solution to yield $24.9 \mathrm{~g}$ Phenyl-OF. One hundred grams of an aromatic adsorptive resin (DIAION ${ }^{\circledR}$ HP20) was suspended in $80 \mathrm{~mL}$ (5,760,000 units) of Lipase $\mathrm{OF}^{\circledR}$ solution to yield $60.3 \mathrm{~g}$ HP20-OF. Twenty five grams of a high porous-type aromatic adsorptive ion exchange resin (DIAION ${ }^{\circledR}$ HPA25) was suspended in $20 \mathrm{~mL}$ $\left(1,440,000\right.$ units) of Lipase $\mathrm{OF}^{\circledR}$ solution to yield $12.5 \mathrm{~g}$ HPA25-OF. Twenty five grams of a methacryl adsorptive resin (DIAION ${ }^{\circledR}$ HP1MG) was suspended in $20 \mathrm{~mL}$ $\left(1,440,000\right.$ units) of Lipase $\mathrm{OF}^{\circledR}$ solution to yield $13.1 \mathrm{~g}$ HP1MG-OF. Forty three grams of Celite ${ }^{\circledR}$ was suspended in $80 \mathrm{~mL}\left(5,760,000\right.$ units) of Lipase $\mathrm{OF}^{\circledR}$ solution to yield $45.5 \mathrm{~g}$ Celite-OF.

\subsection{General enzyme reaction}

Free astaxanthin and an acid donor were placed in a brown glass bottle. Immobilized Candida cylindracea lipase (Lipase $\mathrm{OF}^{\circledR}$ ) and a small amount of water were added, and the mixture was then stirred for 3 or 4 days at $30^{\circ} \mathrm{C}$ to $50^{\circ} \mathrm{C}$. The reaction solution was then taken out, and the same volume of acetone was added. The composition ratio of astaxanthin was analyzed by HPLC (L7000 (Hitachi Co. Ltd., Japan); column: Develosil C30-UG5 (Nomura Chemical Co. Ltd., Japan, 4.6×150 mm, $5 \mu \mathrm{m}$ ); mobile phase: a gradient program of $75 \%$ aq. acetone for 1 min, and from $75 \%$ aq. acetone to $100 \%$ acetone over 15 $\mathrm{min}$, then $100 \%$ acetone for $10 \mathrm{~min}$; flow rate: $1.0 \mathrm{~mL} / \mathrm{min}$; column temperature: ambient; detection wavelength: 480 $\mathrm{nm})$. An area ratio of astaxanthin esters was calculated as the ratio (\%) of the total area of astaxanthin monoester and diester to the total area of astaxanthin esters and unreacted free astaxanthin.

\subsection{The effect of water content in esterification}

Free astaxanthin $(3 \mathrm{mg})$ and WBA-OF (10\% lipase, 300 $\mathrm{mg}$ ) were added to tri- $n$-octanoin $(750 \mu \mathrm{L})$ in a brown glass bottle, and 3.75 (0.5\%), 7.5 (1\%), 15 (2\%), 22.5 (3\%), 37.5 (5\%), or $75 \mu \mathrm{L}(10 \%)$ of water was added to the reaction mixture, or without water $(0 \%)$ as a control. The reaction mixture was stirred for $72 \mathrm{~h}$ at $40^{\circ} \mathrm{C}$.

\subsection{The effect of carriers for immobilization}

Free astaxanthin $(3 \mathrm{mg})$ and the respective immobilized enzyme $(300 \mathrm{mg})$ preparations were added to tri- $n$-octanoin $(750 \mu \mathrm{L})$ in a brown glass bottle, water $(3.75 \mu \mathrm{L})$ was added, and then the reaction mixture was stirred for $72 \mathrm{~h}$ at $40^{\circ} \mathrm{C}$.

\subsection{The effect of acid donor}

Free astaxanthin (2 or $3 \mathrm{mg}$ ) and WBA-OF (10\% lipase, $300 \mathrm{mg})$ were added to tri- $n$-octanoin $(750 \mu \mathrm{L})$ or $n$-octanoic acid $(750 \mu \mathrm{L})$ in a brown glass bottle, water $(3.75 \mu \mathrm{L})$ was added, and then the reaction mixture was stirred for $72 \mathrm{~h}$ at $40^{\circ} \mathrm{C}$.

\subsection{The effect of lipase content in immobilized enzyme preparations}

Free astaxanthin $(3 \mathrm{mg})$ and WBA-OF containing a range of lipase contents $(300 \mathrm{mg})$ were added to tri- $n$-octanoin $(750 \mu \mathrm{L})$ in a brown glass bottle, water $(3.75 \mu \mathrm{L})$ was added, and then the reaction mixture was stirred for $72 \mathrm{~h}$ at $40^{\circ} \mathrm{C}$.

\subsection{Time course of the reaction at the respective tempera- ture}

Free astaxanthin $(3 \mathrm{mg})$ and WBA-OF (10\% lipase, 300 $\mathrm{mg})$ were added to tri- $n$-octanoin $(750 \mu \mathrm{L})$ in a brown glass bottle, water $(3.75 \mu \mathrm{L})$ was added, and then the reaction mixture was stirred for $96 \mathrm{~h}$ at 30,40 , or $50^{\circ} \mathrm{C}$. The area ratio of astaxanthin esters was analyzed at $24,48,72$, and $96 \mathrm{~h}$. 


\section{Enzymatic Synthesis of Astaxanthin Esters}

\section{RESULTS AND DISCUSSION}

\subsection{Water content for enzyme reaction}

In the enzyme reaction using an immobilized lipase, water has to be added to the reaction mixture to activate the lipase ${ }^{12)}$. The optimal amount of water was determined as the percentage volume of water per volume of tri- $n^{-}$ octanoin (MCT). Zero percent means without the addition of water. As shown in Fig. 2, the addition of $0.5 \%(3.75 \mu \mathrm{L})$ water was optimal, and the area ratio of esterified product was ca. $26 \%$. The addition of larger percentage volumes of water reduced the area ratio.

\subsection{The effect of carriers for lipase immobilization}

A hydrophobic anion exchange resin (WBA), Celite ${ }^{\circledR}$, a hydrophobic resin (HP20), a hydrophobic adsorptive resin (Phenyl-650S), a high porous-type aromatic adsorptive ion exchange resin (HPA25), and a methacryl adsorptive resin (HP1MG) were tested as carriers for immobilizing the lipase enzyme. As shown in Table 1, WBA was the best support matrix for the immobilized enzyme. WBA is a hydrophobic anion exchange resin consisting of a styrene polymer with trimethylamine residue attached and is sold as a free form. The surface of Lipase $\mathrm{OF}^{\circledR}$ has acidic regions and it bound in a regio-specific manner to the anionic residue of the resin leaving the active site free to interact with the substrate. The other carriers did not have anionic residues and were unable to bind to the lipase in a manner that retained its activity. Although Celite ${ }^{\circledR}$ is sometimes used as a carrier to immobilize lipase ${ }^{13)}$, in this case the immobilized enzyme exhibited lower activity than when it was bound to WBA.

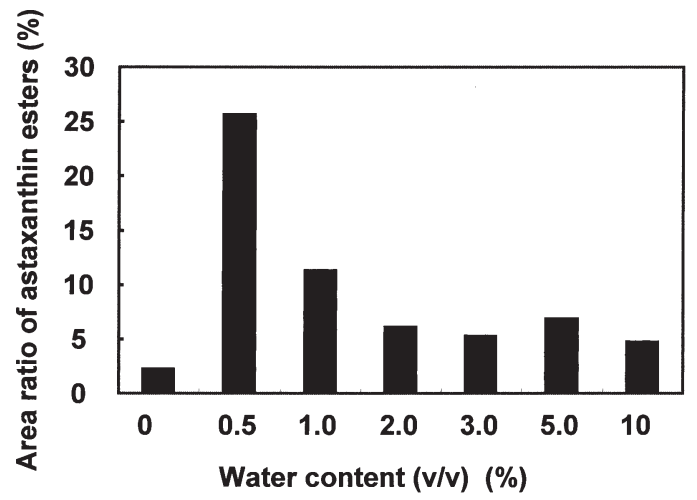

Fig. 2 The Effect of Water Content in Esterification. Free astaxanthin $(3 \mathrm{mg})$ and WBA-OF $(10 \%$ Lipase $\mathrm{OF}^{\circledR}$ immobilized with an anion exchange resin, 300 $\mathrm{mg})$ were added to tri- $n$-octanoin $(750 \mu \mathrm{L})$ in a brown glass bottle, and $0 \%-10 \%$ of water was added to the reaction mixture. The reaction mixture was stirred for $72 \mathrm{~h}$ at $40^{\circ} \mathrm{C}$.

\subsection{The effect of acid donor}

MCT and $n$-octanoic acid were examined as acid donors and as reaction solvents. As shown in Table 2, MCT gave a much better yield. Transesterification is preferred to acidolysis as the reaction in the esterification of astaxanthin.

\subsection{The effect of lipase content on the immobilized enzyme}

The Lipase $O F^{\circledR}$ content in WBA was tested across a range from $2.5 \%$ to $40 \%$. The immobilized enzyme was then used in the esterification of astaxanthin in MCT. As shown in Table 3, 7.5\% and 10\% immobilized enzyme gave the best yields of astaxanthin esters. On the other hand, both lower and higher contents of Lipase $\mathrm{OF}^{\circledR}$ gave lower yields. In the case of $40 \%$ immobilized enzyme, it was speculated that the lipase could not display high activity because most of the Lipase $\mathrm{OF}^{\circledR}$ was stuck to the resin.

\subsection{Time course of the reaction at a range of tempera- tures.}

A time course for 4 days at $30^{\circ} \mathrm{C}, 40^{\circ} \mathrm{C}$, and $50^{\circ} \mathrm{C}$ was examined. As shown in Fig. $3,40-50^{\circ} \mathrm{C}$ was the optimum temperature. The yield increased up to 3 days, but did not

Table 1 The Effect of Carriers for Immobilization.

\begin{tabular}{lc}
\hline Resin & Area ratio of astaxanthin esters (\%) \\
\hline WBA & 26.39 \\
Phenyl-650S & 4.00 \\
HP-20 & 2.07 \\
HP1MG & 3.61 \\
HPA25 & 0.43 \\
Celite $^{\circledR}$ & 3.91 \\
\hline
\end{tabular}

Free astaxanthin $(3 \mathrm{mg})$, the respective immobilized enzymes (300 $\mathrm{mg})$, and water $(3.75 \mu \mathrm{L})$ were added to tri- $n$-octanoin $(750 \mu \mathrm{L})$ in a brown glass bottle and stirred for $72 \mathrm{~h}$ at $40^{\circ} \mathrm{C}$. WBA, Phenyl, HP20, HP1MG, HPA25, and Celite ${ }^{\circledR}$ denote a hydrophobic anion exchange resin, a hydrophobic adsorptive gel, an aromatic adsorptive resin, a methacryl adsorptive resin, a high porous-type aromatic adsorptive ion exchange resin, and clay, respectively.

Table 2 The Effect of Acid Donor.

\begin{tabular}{lcc}
\hline & \multicolumn{2}{c}{ Area ratio of astaxanthin esters (\%) } \\
\cline { 2 - 3 } & MCT & $n$-Octanoic acid \\
\hline Asta $2 \mathrm{mg}$ & 36.40 & 2.47 \\
Asta 3mg & 26.22 & 1.31 \\
\hline
\end{tabular}

Free astaxanthin (2 or $3 \mathrm{mg}$ ), WBA-OF (10\% lipase, $300 \mathrm{mg}$ ), and water $(3.75 \mu \mathrm{L})$ were added to tri- $n$-octanoin $(750 \mu \mathrm{L})$ or $n$-octanoic acid $(750 \mu \mathrm{L})$ in a brown glass bottle and stirred for $72 \mathrm{~h}$ at $40^{\circ} \mathrm{C}$. 
change further even though the reaction was continued for a further $24 \mathrm{~h}$.

From these results, Lipase $\mathrm{OF}^{\circledR}$ immobilized by WBA (10\% w/w content of lipase) gave the best yield in the esterification reaction of astaxanthin. Two $\mathrm{mg}$ of astaxanthin with $750 \mu \mathrm{L}$ MCT (ca. 0.3\%) was optimum because of the low solubility of MCT. Astaxanthin esters were obtained at a yield of $36.4 \%$ under optimal reaction conditions (Table 2, free astaxanthin (2 mg), WBA-OF (10\% lipase, $300 \mathrm{mg}$ ), water $(3.75 \mu \mathrm{L})$ and tri- $n$-octanoin (MCT, $750 \mu \mathrm{L})$ for $72 \mathrm{~h}$ at $40^{\circ} \mathrm{C}$ ). Further studies are needed for additional optimization of the reaction conditions and to increase the yield of astaxanthin ester products.

Table 3 The Effect of Lipase Content in Immobilized Enzyme Preparations.

\begin{tabular}{cc}
\hline Lipase content $^{* 1}$ & Area ratio of astaxanthin esters (\%) \\
\hline $2.5 \%$ & 13.08 \\
$5 \%$ & 16.95 \\
$7.5 \%$ & 26.86 \\
$10 \%$ & 25.42 \\
$20 \%$ & 18.61 \\
$40 \%$ & 10.77 \\
\hline
\end{tabular}

${ }^{* 1}$ Lipase content (\%) in $300 \mathrm{mg}$ of immobilized enzyme.

Free astaxanthin ( $3 \mathrm{mg})$, WBA-OF containing a variety of lipase contents $(300 \mathrm{mg})$, and water $(3.75 \mu \mathrm{L})$ were added to tri- $n$-octanoin $(750 \mu \mathrm{L})$ in a brown glass bottle and stirred for $72 \mathrm{~h}$ at $40^{\circ} \mathrm{C}$.

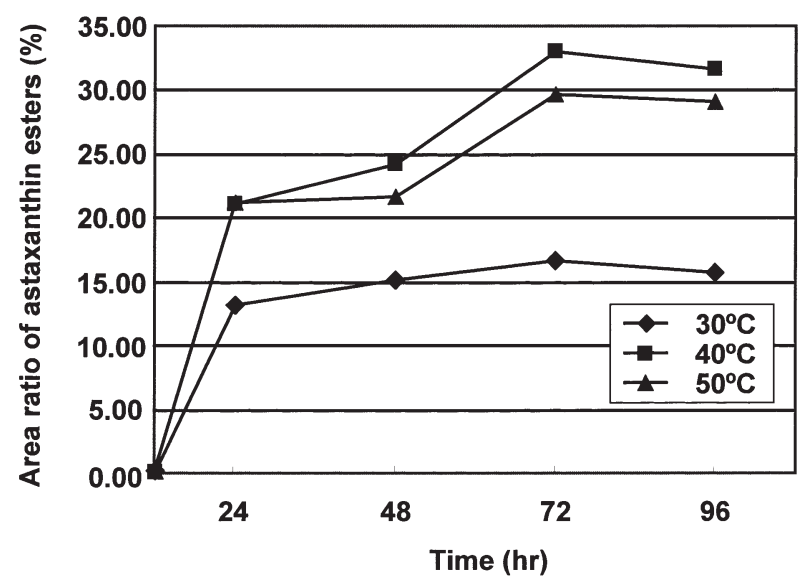

Fig. 3 Time course of the Reaction at a Range of Temperatures.

Free astaxanthin (3 mg), WBA-OF (10\% lipase, 300 $\mathrm{mg})$, and water $(3.75 \mu \mathrm{L})$ were added to tri- $n$ octanoin $(750 \mu \mathrm{L})$ in a brown glass bottle and stirred for $96 \mathrm{~h}$ at the indicated temperatures.

\section{CONCLUSION}

WBA-OF, in which Lipase $\mathrm{OF}^{\circledR}$ was immobilized by a hydrophobic anion resin (Dowex MARATHON ${ }^{\circledR}$ WBA) gave the best yield (36.4\%) in the esterification reaction of astaxanthin. The optimal reaction was conducted in the following condition; free astaxanthin (2 mg), WBA-OF (10\% lipase, $300 \mathrm{mg}$ ), water $(3.75 \mu \mathrm{L})$ in tri- $n$-octanoin (MCT, 750 $\mu \mathrm{L})$ for $72 \mathrm{~h}$ at $40^{\circ} \mathrm{C}$.

\section{References}

1. Matsuno, T.; Hirono, S. Marine carotenoids in Marine Biogenic Lipids, Fats, and Oils, (Ackman, R.G. ed.). Vol. 1, CRC Press, Boca Raton, FL, pp. 251-388 (1989).

2. Miki, W. Biological functions and activities of animal carotenoids. Pure Appl. Chem. 63, 141-146 (1991).

3. Guerin, M.; Huntley, M.E.; Olaizola, M. Haematococcus astaxanthin: Applications for human health and nutrition. Trends Biotechnol. 21, 210-216 (2003).

4. Østerlie, M.; Bierkeng, B.; Liaaen-Jensen, S. Accumulation of astaxhanthin All-E, 9Z and $13 Z$ geometrical isomers and 3 and $3^{\prime} R S$ optical isomers in rainbow trout (Oncorhynchus mykiss) is selective. J. Nutr. 129, 391398 (1999).

5. Johnson, E.A.; An, G.-H. Astaxanthin from microbial sources. Cri. Rev. Biotechnol. 11, 297-326 (1991).

6. Williams, V.R.; Mcmillan, R. Lipids of Ankistrodesmus baunii. Science. 133, 459-460 (1961).

7. Tanaka, Y.; Hibino, H. Jpn Pat. 290094 (1999).

8. Sakado, K.; Mochida, K.; Nishinaka, H.; Abe, T. Jpn Pat. 202261 (1989).

9. Halldorsson, A.; Haraldsson, G.G. Fatty acid selectivity of microbial lipase and lipolytic enzymes from salmonid intestines toward astaxanthin diester. J. Am. Oil Chem. Soc. 81, 347-353 (2004).

10. Fukami, H.; Namikawa, K.; Sugiura-Tomimori, N.; Sumida, M.; Katano, K.; Nakao, M. Chemical synthesis of astaxanthin $n$-octanoic acid monoester and diester and evaluation of their oral absorbability. J. Oleo Sci. 55, 653-656 (2006).

11. Kamata, T.; Simpson, K.L. Study of astaxanthin diester extracted from Adonis aestivalis. Comp. Biochem. Physiol. 86B, 587-591 (1987).

12. Shimada, Y.; Sugihara, A.; Maruyama, K.; Nagao, T.; Nakayama, S.; Nakano, H.; Tominaga, Y. Production of structured lipid containing docosahexaenoic and caprylic acids using immobilized Rhizopus delemar lipase. J. Fermentation Bioengineering 81, 299-303 (1996).

13. Khare, S.K.; Nakajima, M. Immobilization of Rhizopus japonicus lipase on celite and its application for enrichment of docosahexaenoic acid in soybean oil. Food Chem. 68, 153-157 (2000). 